\title{
Russia for Russians: mental representations of image of the country
}

\author{
Svetlana Maximova ${ }^{1}$, Oksana Noyanzina ${ }^{1, *}$, and Daria Omelchenko ${ }^{1}$ \\ ${ }^{1}$ Altai State University, Department of Sociology, 656049, 61 Lenin ave., Barnaul, Russia
}

\begin{abstract}
The article analyzes several components of the image of Russia in borderlands: the Altai krai, the Amur oblast, the Jewish Autonomous oblast, the Transbaikal krai, the Kemerovo oblast, the Omsk oblast, the Orenburg oblast, and the Republic of Altai. Noting, the positive features of the image correlate with international prestige of Russia, historical achievements and cultural heritage, and the negative ones are determined by low standards of living, social inequality and decline of the economy. We found that the parameters of one of the components of Russia's image (identification with a community of citizens) vary considerably depending on the social demographic characteristics: age, sex, and level of material wellbeing, as well as the region of residence.
\end{abstract}

\section{Introduction}

The image of the state is a significant resource of as external as internal policy, important mean of protection of its national interests [1]. Formation of favorable image of the country serves not only political but economical goals too, promoting to the attraction of tourists, development of investments and growth of the export [2]. Peculiarities of perception of the country by population able to effect on its law culture, level of civic participation, social tension and protest activity, indexes of institutional and interpersonal trust. Indirectly, the image of the country may influence on the willingness of citizens to the emigration that may be a serious demographic problem [3].

Existing literature on problems of civic nations describes five general components of civic identity; however, national unity and membership origin from common territory, citizenship, believe in the same political principles or ideology, respect to political institutions, satisfaction by the quality in political rights and commitment to be a part of a nation. Cultural identity bases on non-political cultural characteristics: language, religion, and traditions. Nevertheless, the ethnic identity - bases on common origin and race, acting as the dominant criteria of national identification [4].

In some extent, these three dimensions of national identity differ by the level of inclusiveness, and the 'outsiders' feel difficult to correspond ethnic criteria because they are not free in the choice of the origin. Hence, it is possible to adapt cultural requirements to inter this or those nation. Some citizenship's requirements (for example, the will and agreement) are easy to correspond, but the citizenship depends on not only from the choice

* Corresponding author: noe @ list.ru 
of potential citizen of the state but also from the will of state institutions. Exclusive affiliation to a certain territory me be the additional requirement that outsiders hardly correspond. As the emotional-value component of national identity contains a complex of feelings about the affiliation to concrete nation (proud, dignity, self-respect, joy, love, devotion, resentment, shame, guilty, deprivation, and humiliation) as the state has positive or negative valences.

The image of Russian nowadays could not be marked as unambiguous and stable because of recent social, economic and political transformations, blurring value orientations of the Russians. Researchers point out dissonance between social attitudes of Russians and their representations about real affairs in the country by the end of XX - beginning XXI century that negatively effects the image of Russia [5].

In the modern society, the formation of the state image is closely connected by the influence of the mass media [6] and can became the object of manipulation [7]. Factors, able to influence the image of the country are cinema [8], fiction [9], and printed mass media [10]. During the last years, negative images of Russia prevail in the foreign media. In these conditions, it is very important to monitor the dynamics of perception of the state and develop effective instruments for construction of the image of the country.

\section{Methods}

An analysis of the image of Russian in population's representations realized basing on sociological research 'Civic and ethnic identify of population in border regions' (total sampling $\mathrm{n}=3600$, respondents at the age from 15 to 75). The research covered eight borderland regions of Russian: the Altai krai, the Amur oblast, the Jewish Autonomous oblast, the Transbaikal krai, the Kemerovo oblast, the Omsk oblast, the Orenburg oblast, and the Republic of Altai.

The choice of primary subjects of the Russian Federation was caused by several reasons. First, despite certain difficulties, in contemporary condition there is the necessity of division of large Russian area into regions by these or those types. Secondly, all Russian subjects are differ in the diversity of regional problems of social and economic development and influencing factors.

In connection with this, we took the typology of regions by the Independent social policy Institute as a base for selection of regions. According to the typology, it is necessary of systemize differences in social-economic situation and determine types of subjects of the Russian Federation.

The typology is hierarchic and provides basic differentiating indexes. Of course, their choice in quite subjective, but it bases on expert and analytical experience. There are two such components:

level of economic development of the region and economic condition of households the main differentiating index in transitional Russia, its indicators (GDP, relation of incomes to the living wage and level of poverty) are considered as a unite component to evaluate the production of income, its consumption and inequality in incomes;

level of development of territory, evaluated basing on the density, reflecting the level of favorable climate, type of economic use, provision by infrastructure and so on. This factor is considerably important for the great and diversified Russian territory.

The typology was built in the system of coordinates and lets to determine four extreme 'points' of subjects: «rich» and well developed; «rich» and weakly developed; «poor» and well developed; «poor» and weakly developed.

While having a system of coordinates, it is rather easy to structure other socialeconomic characteristics of regions. They lay on base differences and add the typology. Of course, it is impossible to have full synchrony in change of all components by types. 
Additionally, we found useful to point out general characteristics of regions, which determine as peculiarities of civic and ethnic identity of their residents and interethnic relations too. Data about number of population and ethnic composition based of the AllRussian Population Census (2010).

Principles for the sampling formation included two aspects: the representativeness and the compact distribution, so we used stratified multistage sampling. Since, the sampling is the 'territorial' one, the planning considered correlation between environment and social characteristics of respondents. The sampling is valid by gender, age and type of settlement.

Data possessed with the use of statistic package SPSS 23.0, to base the logic of statistical inference we applied corresponding to the nature of the data (nominative or quantitative) and character of distribution statistical methods (dispersion, regression and factor analysis).

\section{Results}

One of the factors, influencing the formation of country's image, is the understanding of own citizenship and the level of identity with its population. The evaluation of civic identity realized by three parameters: identification with the community of Russians; identification with Russian culture; and emotional perception of the two given factors. According to the data, $93.2 \%$ of respondents (sum of those who 'most likely agree' and 'absolutely agree') consider themselves Russians. In varying degrees, $88.0 \%$ of respondents feel themselves as a part of Russian culture. $85.9 \%$ of respondents feel proud about being Russian, $73.4 \%$ feel happiness about it. Central idea of any nation-state are national symbols. They present visual representations of the collective, its history and achievements. Considering the idea about the state as social construct $[11,12]$, national symbols help to materialize nation and nation-state. National symbols obtain symbolic meaning, including symbolic characteristics. However, the most important, national symbols gain in importance through the inclusion into various cultural practices [13]. Therefore, the symbolic of the state has a significance for contemporary Russians: the most of them feel proud than the state anthem plays or the state flag rises (table 1).

Table 1. The extent of agreement with indexes of civic identity, $\%$.

\begin{tabular}{|l|c|c|c|c|c|}
\hline Statements & $\begin{array}{c}\text { Absolutely } \\
\text { disagree }\end{array}$ & $\begin{array}{c}\text { Most likely } \\
\text { disagree }\end{array}$ & $\begin{array}{c}\text { Do not } \\
\text { know, do } \\
\text { not sure }\end{array}$ & $\begin{array}{c}\text { Most } \\
\text { likely } \\
\text { agree }\end{array}$ & $\begin{array}{c}\text { Absolutely } \\
\text { agree }\end{array}$ \\
\hline $\begin{array}{l}\text { I consider myself as a } \\
\text { Russian }\end{array}$ & 2.1 & 1.1 & 3.5 & 21.5 & 71.7 \\
\hline $\begin{array}{l}\text { I feel myself as a part } \\
\text { of Russian culture }\end{array}$ & 2.3 & 1.7 & 8.1 & 31.2 & 56.8 \\
\hline $\begin{array}{l}\text { I am proud to be a } \\
\text { Russian }\end{array}$ & 2.5 & 1.5 & 10.2 & 26.9 & 59.0 \\
\hline $\begin{array}{l}\text { I am happy to be a } \\
\text { Russian }\end{array}$ & 2.6 & 2.1 & 13.7 & 27.5 & 45.9 \\
\hline $\begin{array}{l}\text { I feel myself proud } \\
\text { than the Russian } \\
\text { anthem plays }\end{array}$ & 2.5 & 2.0 & 9.8 & 28.4 & 57.4 \\
\hline $\begin{array}{l}\text { I feel myself proud } \\
\text { than the Russian flag } \\
\text { rises }\end{array}$ & 2.6 & 1.8 & 10.3 & 28.0 & 57.3 \\
\hline
\end{tabular}

We fixed considerable and significant differences in relation to some socialdemographic characteristics: age, sex and material condition. People of elderly age (50-75 years) are most likely among those who affiliate themselves with Russians and Russian 
culture and feel positive about the state community, rather rare - respondents at the age between 30 and 49 years, and the rarest - the youth (15-29 years). Women demonstrated more expressed characteristics of the civil identity than men did. Values of the abovementioned variables showed differences in relation with the level of material wellbeing: the richer the respondent the higher the agreement with the statements. However, we did not found any similar correlations about the level of education, spheres and character of professional activity, size of settlement of residence, ethnic identity, and religion.

In regions, there were considerable differences in values of studied variables, showing the identification with the Russian community. The highest values of each index were fixed in the Jewish Autonomous oblast, In the Transbaikal krai we marked higher than in total sampling values of indexes related to emotional components of identity - proud or happiness about affiliation with Russian citizenship. The lesser values of emotional component of identity were marked in the Kemerovo oblast, but the part of those who consider them as Russians is the highest in this region. At the same time, inhabitants of the Omsk oblast, the Orenburg region, and the Republic of Altai feel themselves a part of Russian culture rather rare.

To reveal factors, influencing the level of civic identity, we realized regression analysis. The average values of indexes of civic identity aced as dependent variable, and sex, age, material wellbeing and the regions of residence - as independent variable. We found that the highest influence had the region of residence $(\beta=0.123, p<0.01)$ and age $(\beta=0.103$, $\mathrm{p}<0.01$ ) of respondents (table 2).

Table 2. Regression models about prediction of the identification with community of Russians.

\begin{tabular}{|l|c|}
\hline \multicolumn{1}{|c|}{ Predictors } & Standardized coefficients $(\beta)$ of the final model \\
\hline Sex & $0.068^{*}$ \\
\hline Age & $\mathbf{0 . 1 0 3}^{*}$ \\
\hline Material wellbeing & -0.020 \\
\hline Region & $\mathbf{0 . 1 2 3}^{*}$ \\
\hline Final R ${ }^{2}(\%)$ & 31.0 \\
\hline
\end{tabular}

* $\mathrm{p}<0.01$

The notion of the 'state citizen' includes multiple senses, related as to the formal indexes of citizenship, totality of declared rights and duties as to the love to the country and sense of responsibility about it. The most popular answers to the question 'What does it mean to you to be a citizen of the state?' were the following: 'To be a patriot, to love Russia', 'To abide the laws, to respect the Constitution', 'To have all the rights, provided by the laws of the country, to use them', and 'To understand own civic duty, to have civic responsibility, and civic conscience' (table 3). Answers, connected with the love to motherland and civic duties were more spread against those that reflected governmental profits for citizens.

Table 3. Distribution of answers to the question: 'What does it mean to you to be a citizen of the state?', \%.

\begin{tabular}{|l|c|}
\hline \multicolumn{1}{|c|}{ Statements } & 54.0 \\
\hline To abide the laws, to respect the Constitution & 41.4 \\
\hline To have all the rights, provided by the laws of the country, to use them & 32.6 \\
\hline To understand own civic duty, to have civic responsibility, and civic conscience & 30.4 \\
\hline To feel sure and stable in economy and moral sense & 29.2 \\
\hline Constantly live in the country (in the state) & 25.3 \\
\hline Not to have willingness to leave for another country & 24.3 \\
\hline
\end{tabular}




\begin{tabular}{|l|c|}
\hline To be self-actualized person & 14.2 \\
\hline To feel myself affiliated to big and small affairs of the state & 11.9 \\
\hline To respect empowered people & 11.6 \\
\hline
\end{tabular}

Emotional evaluation of the image is rather significant characteristic of it. According to the data, the proud for the country is distributed among $89.5 \%$ of Russians. The most popular bases for the proud are: the victory in the Second World War, image of Russia at the world arena, the president Vladimir Putin, and the great Russian writers and composers (table 4). Considerable part of respondents $(57.0 \%)$ feel shame about own country. Reasons of the feeling are low level of life, low salaries, unemployment, corruption, and decline in industry, agriculture and economy in whole, alcoholism and drug abuse, dominantly (table 5). The above-mentioned categories reflect condition of general components of the image of the state, determined by contemporary researches: political, economic, resource, social, and cultural [14]. Thus, the positive sides of the image of Russia in representations of population are connected with the realization of external policy and cultural heritage, the negative ones - with the quality of life, inefficiency of the government and condition of the economy. Successes of Russian sportsmen do not considerably effect the proud for the country despite a great attention at the state level.

Table 4. Distribution of answers to the question: 'What from the above-mentioned makes you feel proud about Russia?', \%.

\begin{tabular}{|l|c|}
\hline Victory at the Great Patriotic War 1941-1945 & 67.4 \\
\hline Credibility of Russia in the world & 37.8 \\
\hline Russian President Vladimir Putin & 30.6 \\
\hline Great Russian poets, writers, and composers & 30.5 \\
\hline The first successful flight to the Cosmos by Yury Gagarin in 1961 & 21.0 \\
\hline Russian historical past & 20.2 \\
\hline Russian natural resources & 19.0 \\
\hline Achievements of Russian science and technic & 18.9 \\
\hline Successes of Russian sportsmen & 16.4 \\
\hline Acceptation of the Crimea Republic into the Russian Federation & 13.0 \\
\hline Russian army & 11.8 \\
\hline Victories of Russians and international competitions, festivals and so on (music, cinema) & 6.2 \\
\hline
\end{tabular}

Table 5. Distribution of answers to the question: 'What from the above-mentioned makes you feel shame about Russia?’, \%.

\begin{tabular}{|l|c|}
\hline Low level of life, low salaries, unemployment, poverty & 73.0 \\
\hline Corruption, bureaucracy & 47.0 \\
\hline Decline in industry, agriculture, economy in whole & 30.9 \\
\hline Alcoholism, drug use & 28.4 \\
\hline Inactivity, bad work pf government, undeserving behavior of politicians & 21.0 \\
\hline Condition in education, health care system & 17.4 \\
\hline Low level of culture, degradation of the youth & 15.9 \\
\hline Plundering and selling of natural resources, state properties & 15.6 \\
\hline High criminal level, thefts & 9.8 \\
\hline Human right violations & 6.9 \\
\hline Internal policy & 6.1 \\
\hline Position of the country in the world arena, relation to the country abroad & 3.9 \\
\hline Condition in the army, hazing & 3.5 \\
\hline Failures in the sport & 3.2 \\
\hline Internal state policy & 3.0 \\
\hline Relations with the forms Soviet republics & 1.7 \\
\hline
\end{tabular}


One of conditions for effective government and functioning of the institutes of the civil society is the achievement of people's cohesion [15]. The given goal often emerges in contemporary political dialogue as a base for development of patriotic moods and nonconflict interethnic relations [16]. As for the research, 55.8\% of inhabitants of borderland regions consider existence of people's cohesion in Russia, 31.8\% - consider it rather do not exists, and $12.3 \%$ - found difficult to answer.

Bases for people's unity in Russia, according to the data, are 'Russia unites in hard times' and 'people try to help each other' (table 6). The absence of people's cohesion explained by 'the poverty of the most of people, great difference between rich and poor' and 'each thinking only about him/herself' and 'more angry people' (table 7).

Table 6. Distribution of answers to the question: 'Why do you think there is a people's cohesion in Russia?', \%.

\begin{tabular}{|l|c|}
\hline Russian unites in hard times & 68.8 \\
\hline People try to help each other & 35.9 \\
\hline All nations peaceful to each over & 32.8 \\
\hline There are no any wars in the country & 29.8 \\
\hline It is all in our mentality, culture & 27.8 \\
\hline $\begin{array}{l}\text { People united during the acceptation of the Crimea Republic and the Sevastopol into the } \\
\text { Russian Federation }\end{array}$ & 26.7 \\
\hline People love own country & 23.4 \\
\hline People participate mass sport and cultural events together & 22.0 \\
\hline People united during the President's elections & 8.0 \\
\hline
\end{tabular}

Table 7. Distribution of answers to the question: 'Why do you think there are no any people's cohesion in Russia?', \%.

\begin{tabular}{|l|c|}
\hline People live in poverty, a great difference between rich and poor & 63.8 \\
\hline The each think for him/herself and about him/herself & 48.5 \\
\hline People became more angry & 47.5 \\
\hline There are no any common goal, idea, patriotism & 29.4 \\
\hline The state tried to divide people & 14.8 \\
\hline Multiethnic society & 9.3 \\
\hline
\end{tabular}

To describe the image of the country we used a method of factor analysis as a method of research and, at the same time, form of model representation of categorical structures of consciousness. The content of factors included into analysis - bases for categorization reflected the forms of unifications used by subjects and formed personal perceptive etalon. Table 8 presents factor structure based on data of total sampling (table 8).

In a result of factor analysis of representations of Russian inhabitants about the country we determined 5 significant factors, explaining $57.781 \%$ of cumulative dispersion. The first factor describes $13.577 \%$ of total dispersion, the second significant factor $-13.024 \%$ of dispersion, the third $-12.070 \%$, the fourth $-10.897 \%$, and the firth $-8.213 \%$.

The first factor was constructed the following variables, included with positive loadings: economy potential, new markets and economic possibilities $(a=0,692)$; great scientific and geography discoveries $(a=0,551)$; effective system of education, prestigious educational institutions $(a=0,775)$; achievements of Russian sportsmen $(a=0,495)$; attractiveness for travels and tourism $(\mathrm{a}=0,575)$; intelligence, self-education of Russians $(\mathrm{a}=0,562)$. Thus, the first factor was fulfilled by variables, describing social-economic aspects of the image of Russia, historically significant events, natural-geographic characteristics of the country, attractive for tourism, and personal character of Russians. In 
total, the given factor may be characterized as the image of effective country - successful and attractive in economy, education, science, sport, and tourism sense.

By the second factor, the role position of the image of Russia in representations of inhabitants of Russian regions was fulfilled by the following constructs: strong state and great power $(a=0,518)$; readiness to help in case of natural disasters, cataclysms and provide humanitarian help $(a=0,742)$; hospitality, peaceful and friendly people $(a=0,526)$; peace-making policy, help to other countries in conflict regulation $(a=0,733)$; military power, nuclear potential of Russia $(\mathrm{a}=0,600) 1$ the President Vladimir Putin $(\mathrm{a}=0,578)$. Thus, the variables entered into the second factor with high positive loadings describe political characteristics including foreign policy and reflecting evaluation of the country at the international arena as a country that ready to help other states, enforced by characteristics of strong and military powerful state with strong president. The only feature that did not corresponded to the constructed political image - hospital and friendly characteristics of Russians. From the other hand, the image of Russia as a country ready for provision of any help to other countries rather correlates with the image of hospital inhabitants. The second factor in the image of Russia may be called as 'political image of the country'.

The third factor consisted of the following variables: rich natural and primary resources $(\mathrm{a}=0,760)$; beautiful nature, diversity of climatic zones $(\mathrm{a}=0,745)$; great territory and huge areas $(a=0,755)$; possession and research of the Cosmos, development of aeroCosmic technologies $(\mathrm{a}=0,494)$; victory in the Second World War $(\mathrm{a}=0,505)$.

So, the third factor consisted of variables describing natural-geographic characteristics of Russia and historical events, having a special significance for the formation of national identify of Russians. However, the factor reflects not only historical-geographic image of the country but has symbolic sense for the most of Russians and is translated into such symbols as a great territory, natural resources, different landscapes, cosmos flights, and the victory in the Second World War. That is why the third factor reflects the symbolicgeography image of the country.

The fourth factor of the role position 'image of Russia' in representations of inhabitants consisted from the following constructs: Russian culture and arts (Russian literature, ballet, cinema and etc.) $(\mathrm{a}=0,522)$; the Orthodoxy, Russian churches, icons $(\mathrm{a}=0,647)$; diversity of ethnos and cultures $(\mathrm{a}=0,591)$; position between the West and the East, a special way of development $(a=0,448)$; mysterious Russian soul, mentality of Russian people $(a=0,633)$. The fourth factor has evident cultural dimension and includes variables describing spiritualcultural aspects of the image of Russia. It reflects the specifics of Russian culture, residing multiple nations and ethnos, indicates intermediate positions between cultures of the West and the East and correlation between the image of the country and the Orthodoxy and Great Russian culture.

The firth factor is fulfilled by the following constructs: contradiction between Russia and Wester countries (Europe, the USA) $(\mathrm{a}=0,637)$; Soviet Union, the Communist past (a $=0,728)$; attractiveness for labor migration, opportunities to earn $(\mathrm{a}=0,536)$. Here we fix the uniting of historical past (Soviet Union) and political factor reflecting tendencies of confrontation with the western countries. The factor translates civilization image of Russia, opposite to the image of the West and American states and may be characterized as the western antipode.

Table 8. Results of factor analysis. 


\begin{tabular}{|c|c|c|c|c|c|}
\hline \multirow{2}{*}{ Descriptors } & \multicolumn{5}{|c|}{ Competent } \\
\hline & 1 & 2 & 3 & 4 & 5 \\
\hline Rich natural and primary resources & 0.084 & 0.135 & 0.760 & 0.055 & 0.228 \\
\hline Beautiful nature, diversity of climatic zones & 0.139 & 0.107 & 0.745 & 0.227 & -0.051 \\
\hline Great territory, huge areas & -0.007 & 0.220 & 0.755 & 0.081 & 0.164 \\
\hline $\begin{array}{l}\text { Possessing and research of the Cosmos, } \\
\text { development of aerocosmic technologies }\end{array}$ & 0.358 & 0.172 & 0.494 & 0.183 & 0.177 \\
\hline $\begin{array}{l}\text { Russian culture and arts (Russian literature, } \\
\text { painting, ballet, cinema and etc.) }\end{array}$ & 0.281 & -0.011 & 0.438 & 0.522 & -0.047 \\
\hline $\begin{array}{l}\text { Economic potential, new markets, economic } \\
\text { opportunities }\end{array}$ & 0.692 & 0.177 & 0.194 & 0.055 & 0.235 \\
\hline Strong state, great power & 0.488 & 0.518 & 0.279 & 0.048 & 0.110 \\
\hline Victory in the Second World War & 0.160 & 0.427 & 0.505 & 0.140 & -0.003 \\
\hline Great scientific and geography discoveries & 0.551 & 0.165 & 0.343 & 0.280 & 0.019 \\
\hline $\begin{array}{l}\text { Effective system of education, prestigious } \\
\text { educational institutions }\end{array}$ & 0.775 & 0.106 & 0.011 & 0.137 & 0.194 \\
\hline Achievements of Russian sportsmen & 0.495 & 0.361 & 0.173 & 0.082 & 0.239 \\
\hline $\begin{array}{l}\text { Confrontation between Russia and Western } \\
\text { countries }\end{array}$ & 0.206 & 0.293 & 0.149 & 0.105 & 0.637 \\
\hline Soviet union, the Communist past & 0.083 & 0.051 & 0.170 & 0.200 & 0.728 \\
\hline $\begin{array}{l}\text { Attractiveness for labor migration, opportunities } \\
\text { to earn }\end{array}$ & 0.411 & 0.224 & -0.053 & 0.119 & 0.536 \\
\hline Country, attractive for travels and tourism & 0.575 & 0.171 & 0.077 & 0.334 & 0.069 \\
\hline $\begin{array}{l}\text { Readiness to help other countries in case of } \\
\text { natural disasters, cataclysms and provide } \\
\text { humanitarian help }\end{array}$ & 0.135 & 0.742 & 0.202 & 0.270 & 0.100 \\
\hline Hospitality, peaceful and friendly people & 0.358 & 0.526 & 0.132 & 0.457 & -0.027 \\
\hline $\begin{array}{l}\text { Peace-making policy, help to other countries in } \\
\text { conflict regulation }\end{array}$ & 0.217 & 0.733 & 0.171 & 0.263 & 0.166 \\
\hline Military power, nuclear potential of the country & 0.191 & 0.600 & 0.297 & 0.098 & 0.289 \\
\hline Intelligence, good education of Russians & 0.562 & 0.144 & 0.035 & 0.529 & 0.070 \\
\hline The Orthodoxy, Russian churches and icons & 0.143 & 0.213 & 0.129 & 0.647 & 0.265 \\
\hline Diversity of ethnos and cultures & 0.016 & 0.278 & 0.271 & 0.591 & 0.173 \\
\hline $\begin{array}{l}\text { Position between the East and the West, a } \\
\text { special way of development }\end{array}$ & 0.257 & 0.241 & 0.140 & 0.448 & 0.411 \\
\hline President Vladimir Putin & 0.149 & 0.578 & 0.070 & 0.205 & 0.336 \\
\hline $\begin{array}{l}\text { Mysterious Russian soul, mentality of Russian } \\
\text { people }\end{array}$ & 0.255 & 0.265 & 0.094 & 0.633 & 0.200 \\
\hline
\end{tabular}

\section{Conclusions}

Results of the research showed that positive characteristics prevail in representations of Russians about Russian. Russian citizenship and image of Russia, understanding of own civic identity provoke positive emotions too. Dominantly, positive features in the image of Russia are connected with the position of the country in the world arena, historical achievements and cultural heritage - these categories often used in the propaganda work 
and patriotic education, in the most cases. At the same time, in perceptions of Russia there are number of negative characteristics related to low level of life, social inequality, corruption and bureaucracy. Noting, these components keep preserved from the 90 s of the XXst century [17], their alleviation is impossible without change in real condition of economic system and provision of stable social guarantees for population.

By results of factor analysis in representations of Russians we revealed five sub-images of the country: image of effective country, political image, symbolic historical-geographic image, spiritual-cultural image, and image of the Western antipode. The image of effective country in the representations of Russians reflects social-economic aspects of country's development, historically-important aspects in the development, natural-geographic characteristics and personal characteristics of Russian people who demonstrate achievements in different spheres.

Political image translates the image of strong military state, having peace-making policy in relation to other countries. The symbolic-geography image contains representations about natural-geographic characteristics and key historical events such as the victory in the Second World War and possession of the Cosmos. Cultural image of the country reflects rich cultural heritage - culture of various ethnos, classical Russian culture and arts, the Orthodox religious traditions. We also fixed the image of Russia as an antipode to the West in whole, translating a special civilization image of Russian in the contradictory to the image of the West and the USA, in particular.

\section{References}

1. I. Stepanova, Corporative imagology, 01 (01) (2007).

2. K. Dinnie, Nation Branding. Concepts, Issues, Practice, 264 (2008).

3. Ya. V. Symchera, Internal migration of population in contemporary Russia (Candidate thesis, 2003).

4. S. G. Maximova, O. Ye. Noyanzina, D. A. Omelchenko, M. B. Maximov \& G. C. Avdeeva, International journal of environmental \& science education, 11, 11, pp. 4885-4893 (2016)

5. A. N. Kirkin, Formation of the state image in political consciousness of Russians (Candidate thesis, 2006).

6. I. V. Sidorskaya, 'Look' or 'image' of the country: what the mass media represent (2015).

7. G. A. Gavrilov, Actual questions of Philosophy, pp. 154-156 (2011).

8. T. E. Grinberg, Mediascope, 2 (2008).

9. A. Fedorov, European Researcher, 53 6-2, pp. 1772-1786 (2013).

10. O. Sidorova, Quaestio Rossica, 4, 2, pp. 183-194 (2016).

11. E. C. Kaloeva, Youth scientists in solving actual problems of the science, pp. 538-541 (2014).

12. B. Anderson, Imagined communities: Rejections on the origins and spread of nationalism (1983).

13. E. Hobsbawm, T. Ranger, The Invention of Tradition (1983).

14. C. Marvin, D. W. Ingle, Blood sacrifice and the nation: Totem rituals and the American flag (1999).

15. Pew Research Center. Global Attitudes \& Trends (2014).

16. S. N. Smirnov, A. K. Kapustin, N. I. Isaev, Russia’s World, 4, pp. 63-90 (2012). 
17. A. V. Krasnitskaya, A. Yu. Achmis, Humanitarian, social-economic and social sciences, 4, pp. 243-246 (2014). 